\title{
Effect of transport on pulsatile LH release in ovariectomized ewes with or without prior steroid exposure at different times of year
}

\author{
H. Dobson, J. E. Tebble, M. Ozturk* and R. F. Smith \\ Department of Veterinary Clinical Science and Animal Husbandry, University of Liverpool, Leahurst, Neston, \\ South Wirral L64 7TE, UK
}

The initial aim of the present study was to test whether the stress of transport suppresses LH pulsatile secretion in ewes. In a pilot experiment in the late breeding season, transport resulted in an unexpected response in three out of five transported, ovariectomized ewes pretreated with oestradiol and progesterone. Before transport, seasonal suppression of LH pulses had occurred earlier than anticipated, but LH pulsatility suddenly restarted for the period of transport. This finding was reminiscent of unexplained results obtained in ovariectomized ewes infused centrally with high doses of corticotrophin-releasing hormone after pretreatment with low doses of oestradiol with or without progesterone. Hence, an additional aim of the present study was to examine whether these latter results with corticotrophin-releasing hormone could be reproduced by increasing endogenous corticotrophin-releasing hormone secretion by transport. Subsequent experiments used groups of at least eight ovariectomized ewes at different times of the year with or without prior exposure to steroids to assess whether these unexpected observations were associated with season or the prevailing endocrine milieu. In the mid-breeding season, transport for $4 \mathrm{~h}$ in the absence of steroid pretreatment for 8 months reduced $\mathrm{LH}$ pulse frequency from $7.5 \pm 0.3$ to $6.3 \pm 0.4$ pulses per $4 \mathrm{~h}(P<0.05)$ and LH pulse amplitude from $2.6 \pm 0.5$ to $1.8 \pm 0.3$ $\mathrm{ng} \mathrm{m} \mathrm{l}^{-1}(P<0.05)$. Similarly, in the mid-breeding season, $34 \mathrm{~h}$ after the cessation of pretreatment with oestradiol and progesterone, transport suppressed LH pulse frequency from $6.1 \pm 0.4$ to $5.5 \pm 0.3$ pulses per $4 \mathrm{~h}(P<0.05)$ with a tendency of effect on amplitude $\left(6.2 \pm 2.7\right.$ to $2.61 \pm 0.6 \mathrm{ng} \mathrm{ml}^{-1} ; P=0.07$; note the large variance in the pretransport data). During mid-anoestrus, evidence of a suppressive effect of transport was only observed on LH pulse amplitude $(4.7 \pm 0.6$ versus $3.0 \pm 0.5$ pulses per $4 \mathrm{~h}$; $P<0.05)$ in ovariectomized ewes that had not been exposed to ovarian steroids for 4 months. Repetition of the pilot experiment with 12 ewes during the transition into anoestrus resulted in one ewe with $\mathrm{LH}$ pulses seasonally suppressed but increased by transport; 11 ewes had a distinct pulsatile LH pattern which was decreased by transport in six ewes. In anoestrus, there was no effect of transport on LH pulse frequency or amplitude in intact ewes, or those ovariectomized 2-3 weeks previously, with or without prior oestradiol and progesterone treatment. However, basal concentrations of cortisol were greater in anoestrus than in the breeding season, and the increment in cortisol during transport was similar in anoestrus and the breeding season but greater during the transition into anoestrus $(P<0.05)$. Progesterone concentrations increased from $0.31 \pm 0.02 \mathrm{ng} \mathrm{ml}^{-1}$ before transport to $0.48 \pm 0.05 \mathrm{ng} \mathrm{ml}^{-1}$ during the second hour of transport $(P<0.05)$. In conclusion, transport reduced LH pulse frequency and amplitude in ovariectomized ewes that had not been exposed to exogenous steroids for at least 4 months. In most animals, the previously observed increase in LH pulsatility induced by exogenous $\mathrm{CRH}$ was not reproduced by increasing endogenous CRH secretion by transport. However, in four ewes, transport did increase LH pulsatility, but only during the transition into anoestrus in ewes with seasonally suppressed LH profiles after withdrawal of steroid pretreatment.

*Present address: Uzman Veteriner Hekim, Pendik Veteriner, Kontrol ve Arastirma Enstitusu, Pendik-Istanbul, Turkey 


\section{Introduction}

Activation of the hypothalamus-pituitary-adrenal axis by a stressor causes subfertility in animals by reducing secretion of LH from the pituitary (for review, see Phogat et al., 1997a). Before a normal preovulatory $\mathrm{LH}$ surge, $\mathrm{LH}$ is secreted in a pulsatile pattern to form an important impetus for oestradiol production by the growing follicle (Dobson et al., 1997; Campbell et al., 1998). In intact ewes, this increase in oestradiol contributes to the mechanism controlling the timing of the onset of the LH surge. Consequently, knowledge concerning the mechanism by which stressors reduce LH pulsatility may explain the aetiology behind stress-induced subfertility. Transport stress has been shown to delay the onset of the preovulatory surge, but results concerning the effects on pulsatility in the late follicular phase were confounded by feedback effects of the high concentration of oestradiol at this time (Dobson et al., 1999a).

Consequently, the initial aim of the present study was to test the hypothesis that stressors suppress LH pulsatile secretion in ovariectomized ewes. A pilot experiment in the late breeding season revealed completely opposite results to those expected, that is, transport increased LH pulsatility in three out of five ovariectomized ewes pretreated with oestradiol and progesterone. This finding was reminiscent of unexplained results obtained in ovariectomized ewes infused centrally with high doses of corticotrophin-releasing hormone (CRH) after pretreatment with low doses of oestradiol with or without progesterone (Caraty et al., 1997). Hence, an additional aim of the present study was to examine whether these latter results with $\mathrm{CRH}$ could be reproduced by increasing endogenous $\mathrm{CRH}$ secretion by transport (Smith et al., 1997). The observations from the pilot experiment could have been due to prior oestradiol or progesterone exposure, the time of year or the absence of other unknown substances from the ovaries. Subsequent experiments used groups of ovariectomized or intact ewes transported with or without prior exposure to oestradiol or progesterone at various times of the year.

\section{Materials and Methods}

\section{Animals, hormone preparations and collection of blood samples}

Suffolk or Cheviot cross-bred mature ewes weighing between 50 and $75 \mathrm{~kg}$ were used in this series of experiments. The ewes were loosely housed together in a barn and held in a restricted area to carry out each procedure. Concentrate feed was provided twice a day with hay and water ad libitum.

The experiments started 6 months after the ovaries of 12 ewes had been removed under general anaesthesia in September (the start of the breeding season in our flock) to avoid the pain involved in transporting recently ovariectomized animals. Unless stated otherwise, a small s.c. oestradiol implant $(10 \mathrm{~mm} \times 3.3 \mathrm{~mm}$; Ozturk et al., 1998) was inserted during ovariectomy and remained subcutaneous throughout the experimental series to ensure that the ewes were exposed to a similar steroid milieu as intact animals. In addition, from September to February (the breeding season immediately after ovariectomy), artificial oestrous cycles were maintained by 12 days administration of luteal concentrations of progesterone using intra-vaginal devices (CIDR-G, InterAg, Hamilton; Wheaton et al., 1993). Sixteen hours after progesterone withdrawal, four large oestradiol implants $(30 \mathrm{~mm} \times 3.3 \mathrm{~mm})$ were inserted s.c. and removed $66 \mathrm{~h}$ after progesterone withdrawal followed $24 \mathrm{~h}$ later by insertion of new CIDR-Gs to begin the next cycle (Moenter et al., 1990).

In February, a preliminary transport experiment was conducted. Thereafter, for the subsequent 8 months from February to October, all implants were removed to ensure prolonged absence of oestradiol and progesterone before the next experiment, which occurred during the breeding season, 13 months after ovariectomy. The same ewes were used in each part of each individual experiment to reduce the effect of variation among individuals. Ewes have a similar arginine vasopressin (AVP), $\mathrm{CRH}$, adrenocorticotrophin hormone $(\mathrm{ACTH})$ or cortisol response when repeatedly transported at intervals of more than 7 days (Smith et al., 1997).

Before each experiment, all ewes were accustomed to human contact and mock sampling procedures for at least 10 days to minimize the effect of this stressor during the experimental period. One day before each experiment, indwelling catheters were inserted into the jugular vein under local anaesthesia in all ewes and catheter patency was maintained by filling with heparinized saline $\left(100 \mathrm{iu} \mathrm{ml^{-1 }}\right)$. In each experiment, blood samples were taken every $10 \mathrm{~min}$ for a $4 \mathrm{~h}$ period before, during and for 6 or $8 \mathrm{~h}$ after, transport. The samples $(4 \mathrm{ml})$ were collected into heparinized tubes and immediately centrifuged at $1000 \mathrm{~g}$ for $20 \mathrm{~min}$. Plasma was stored at $-15^{\circ} \mathrm{C}$ until analysed.

\section{Transport}

When indicated, ewes were transported in groups of 12 in an enclosed truck $(4 \mathrm{~m} \times 2 \mathrm{~m})$ along metalled roads for $4 \mathrm{~h}$. When the group sizes for this experiment were $<12$, extra animals from another experiment were included to maintain a constant number of animals being transported at any one time. Blood samples were collected during transport without the vehicle stopping. After transport, the ewes were returned to the original barn and sampling continued. Transport began at the same time of day (noon) in each experiment to avoid any complication of possible diurnal effects.

\section{Experimental design}

The experimental protocol is summarized (Fig. 1).

Pilot experiment: late breeding season, with prior steroid treatment. In February, before ovarian cyclicity had ceased in most of the flock (monitored with a vasectomized ram and intact ewes; data not shown), ten ovariectomized ewes had the last artificial luteal phase of the breeding season imposed Downloaded from Bioscientifica.com at 04/26/2023 09:14:26AM 
Breeding season

\begin{tabular}{lc}
$\begin{array}{l}\text { Experiment } 1 \\
\text { ( } n=12 \text { ewes })\end{array}$ & No steroids \\
& 12 day \\
\hline $\begin{array}{l}\text { Experiment } 2 \\
(n=8 \text { ewes })\end{array}$ & Progesterone \\
\hline
\end{tabular}

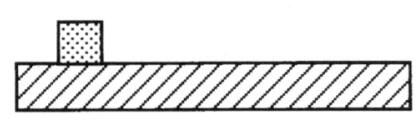

( $n=8$ ewes)

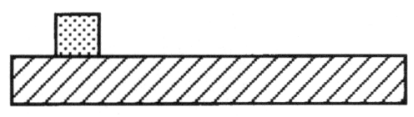

Transition into anoestrus

Experiment 3

12 day

( $n=12$ ewes)

\begin{tabular}{|l|}
\hline Progesterone \\
\hline $10 \mathrm{~mm}$ oestradiol \\
\hline
\end{tabular}

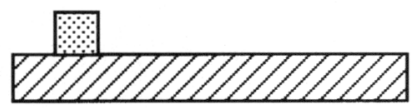

Anoestrus

$\begin{array}{lll}\begin{array}{l}\text { Experiment } \\ (n=12 \text { ewes) }\end{array} & \text { (a) } & \text { No steroids } \\ & & 12 \text { day } \\ \text { ( } n=6 \text { ewes) } & \text { (b) } & 10 \mathrm{~mm} \text { oestradiol } \\ & & 12 \text { day } \\ \text { (n=6 ewes) } & \text { (c) } 10 \text { mm oestradiol }\end{array}$

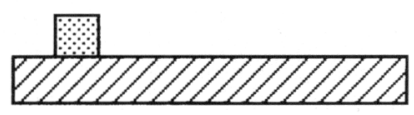

Anoestrus: recently ovariectomized

$\begin{array}{lll}\begin{array}{l}\text { Experiment } \\ \text { ( } n=12 \text { ewes) }\end{array} & \text { (a) } & \text { No steroids } \\ & \\ \text { ( } n=12 \text { ewes) } & \text { (b) } & 7 \text { day } \\ & & \text { Progesterone } \\ 10 \mathrm{~mm} \text { oestradiol }\end{array}$

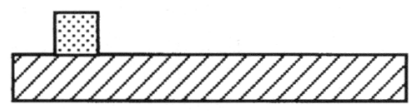

Anoestrus: intact ewes

Experiment 6
$(n=8$ ewes $)$

No exogenous steroids

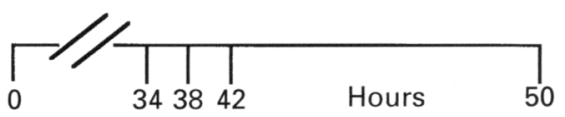

Fig. 1. Experimental design: the periods of steroid treatment are indicated by the labelled horizontal bars; 7 , time of transport; $\square$, blood sampling. The horizontal scale relates to the time after progesterone removal or an equivalent time in ewes not treated with steroids.

by administration of progesterone (two CIDR-Gs) along with the small s.c. oestradiol implant. Closer synchrony of LH surges is achieved using two devices rather than one (Kelly et al., 1996). After 12 days of this treatment, all steroids were withdrawn and five ewes were further monitored as nontransported controls. The other five ewes were transported for $4 \mathrm{~h}$ starting $38 \mathrm{~h}$ after steroid withdrawal. This is before the time when an oestradiol-induced LH surge would have begun if the animals had been subjected to further oestradiol treatment to simulate the follicular phase of intact animals (40-60 h; Dobson et al., 1999a).

Experiment 1: mid-breeding season, no prior steroids. In October, 13 months after ovariectomy, all 12 ewes (Group 1) 
were transported for $4 \mathrm{~h}$ without ovarian steroids having been administered for the preceding 8 months.

Experiment 2: mid-breeding season, with prior steroids. Two weeks later, eight ewes were transported but, in the intervening period, each ewe received two CIDR-Gs and a small oestradiol implant for 12 days. On day 14, the ewes were transported for $4 \mathrm{~h}$, starting $38 \mathrm{~h}$ after simultaneous progesterone and oestradiol withdrawal.

Experiment 3: transition into anoestrus, with prior steroids. For the remaining 4 months of the breeding season, the ewes were subjected to artificial oestrous cycles, including the continuous insertion of the small oestradiol implant. In early March, when ovarian cyclicity in the flock was beginning to cease (confirmed by simultaneous monitoring of intact ewes; data not shown), all 12 ovariectomized ewes were transported for $4 \mathrm{~h}$, starting $38 \mathrm{~h}$ after simultaneous withdrawal of the small oestradiol implants and progesterone devices, which had been inserted for 12 days. This experiment was carried out 2 weeks later in the year than the pilot experiment to ensure greater numbers of ewes just entering anoestrus.

Experiment 4: anoestrus, with or without prior steroids. During July, all 12 ewes (now ovariectomized 17 months previously) were transported for $4 \mathrm{~h}$ without ovarian steroids having been administered for the preceding 4 months (Expt 4a). Ewes were transported 2 weeks later but, in the intervening period, two CIDR-Gs plus one small oestradiol implant per ewe were inserted for 12 days to examine the effect of progesterone with or without the maintenance of oestradiol influence. In Expt $4 \mathrm{~b}$, all steroids were then removed from half the ewes whereas, in the remaining six ewes (Expt 4c), the CIDR-Gs were removed but the small oestradiol implant remained throughout the experiment. All ewes were transported from 38 to $42 \mathrm{~h}$ after progesterone withdrawal.

Experiment 5: anoestrus, recently ovariectomized ewes, with or without prior steroids. As the ewes in the previous experiment had been ovariectomized for more than 1 year, Expt 4 was repeated using 12 new ewes ovariectomized in late July in a cross-over design. All ewes were free from exogenous steroids for 7 days after ovariectomy. Subsequently, half the ewes remained unexposed to steroids for at least 7 days before transport (Expt 5a) whereas the remaining ewes had two CIDR-Gs and small oestradiol implants inserted for 7 days (Expt 5b). All 12 ewes with or without prior steroid treatment were transported for $4 \mathrm{~h}$, beginning $38 \mathrm{~h}$ after steroid removal, or an equivalent period in the ewes not treated with steroids. The day after this transport session, the steroid treatments were crossed over and a second series of samples was taken 8 days later, effectively providing 12 replicates for each of the two treatments.

Experiment 6: anoestrus, intact ewes without prior exogenous steroids. Expt 4a was repeated in August using eight intact ewes (except that the ewes were not bled for the $4 \mathrm{~h}$ period after transport) to ensure that the effects were not masked by other unknown compounds from the ovaries.

\section{Hormone analysis}

Pulsatile LH patterns were examined using the modified method of Dobson and Ward (1977), (analysing 200 rather than $100 \mu \mathrm{l}$ plasma), and results were expressed as ng equivalents of NIAMDD ovine LH $21 \mathrm{ml}^{-1}$ plasma. Methods characterized and verified in this laboratory were used to measure cortisol (Alam et al., 1986) and progesterone (Kanchev et al., 1976). However, the separation of bound and unbound hormone in the steroid assays was modified. Instead of using charcoal at the end of the incubation period, $2 \mathrm{ml}$ scintillant (Insta Fluor LSC, Canberra-Packard Ltd, Pangbourne) was added; the tubes were vigorously shaken for $30 \mathrm{~s}$, allowed to stand for $5 \mathrm{~min}$ and the fluid phases then separated by freezing the aqueous phase in an alcohol bath at $-20^{\circ} \mathrm{C}$. The organic scintillant phase was decanted into counting vials.

Interassay and intra-assay coefficients of variation for $\mathrm{LH}$ $(200 \mu \mathrm{l})$, cortisol and progesterone were both $<9.0,9.5$ and $7.1 \%$, respectively, with minimum detectable quantities of $0.1 \mathrm{ng} \mathrm{ml}^{-1}$, $0.4 \mathrm{ng} \mathrm{ml}^{-1}$ and $0.025 \mathrm{ng} \mathrm{ml}^{-1}$, respectively, and assay precision in the mid-range of the standard curve of $0.1,0.2$ and $0.01 \mathrm{ng}$ $\mathrm{ml}^{-1}$, respectively. Measurements of progesterone were unaffected when an amount of cortisol equivalent to $80 \mathrm{ng} \mathrm{ml}^{-1}$ was added to plasma samples containing $<0.5 \mathrm{ng}$ progesterone $\mathrm{ml}^{-1}$, which confirmed the absence of crossreaction artefacts.

\section{Statistical analysis}

The LH pulses were identified using the Munro algorithm (Taylor, 1987) as described in detail by Dobson et al. (1999a). The windows of analysis, which defined the number of samples used to calculate the mean values for periods of comparison, were set at $240 \mathrm{~min}$ for the $4 \mathrm{~h}$ periods before, during and after transport. As there was variability in the time taken to resume pulsatility after transport, the period from 10 to $14 \mathrm{~h}$ (2-6 h after transport) was used for analysis.

Values were transformed before statistical analysis $\left(\log _{10}\right.$ transformed for hormone concentration and pulse amplitude, and square-root transformed for pulse frequency; Battaglia et al., 1997). Mean LH concentration, pulse amplitude and frequency between control and transported ewes were compared on a within ewe basis before and during transport using Student's one-tailed paired $t$ test. In experiments using the same ewes, comparisons among treatments were made on a paired basis to circumvent interanimal variation; otherwise unpaired tests were used.

The amount of cortisol or progesterone released over a given period was represented by the area under the concentration curve for samples collected during each hour of transport minus the basal secretion during the hour before transport. Comparisons were made by Student's $t$ test.

\section{Results}

\section{LH}

Pilot experiment: late breeding season, with prior steroids. The results obtained for three of the five ewes were opposite to 

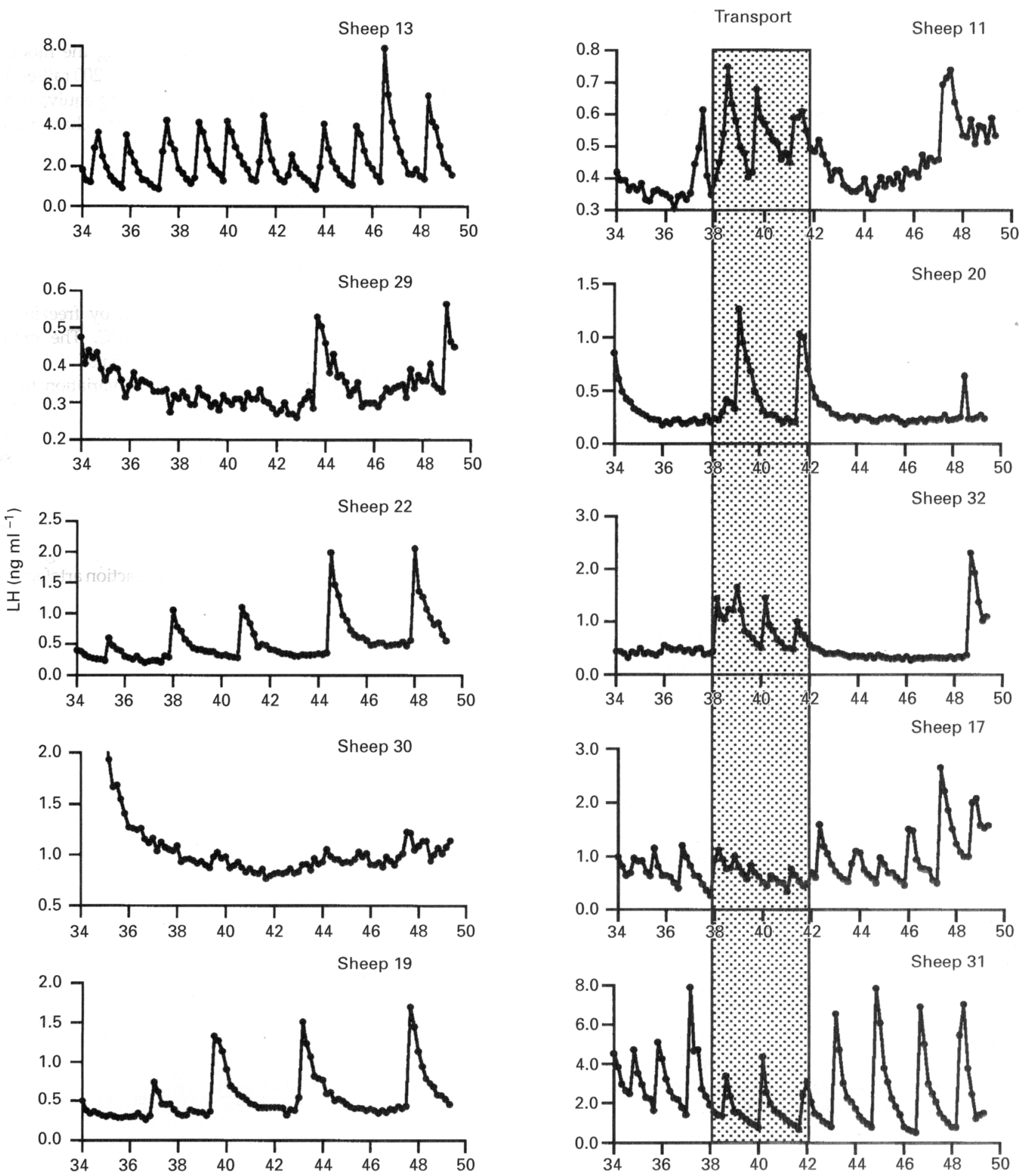

Time after removal of implants (h)

Fig. 2. Profiles of LH in ovariectomized ewes after steroid removal in the pilot experiment during the transition into anoestrus in control ewes (left panel) and during transport ( $)$; right panel). Note the different vertical scales. Also note the reversal of effect in the top three transported ewes.

those expected (Fig. 2). The LH pulse amplitude, by now seasonally suppressed in these three ewes, suddenly increased for the period of transport, and then reverted to the suppressed pattern. The remaining two ewes conformed to the expected hormone profile, showing a decrease in LH pulsatility during transport. Three of the control ewes had a pulsatile LH profile, whereas regular pulsatility was not observed in the other two control ewes. In view of this 


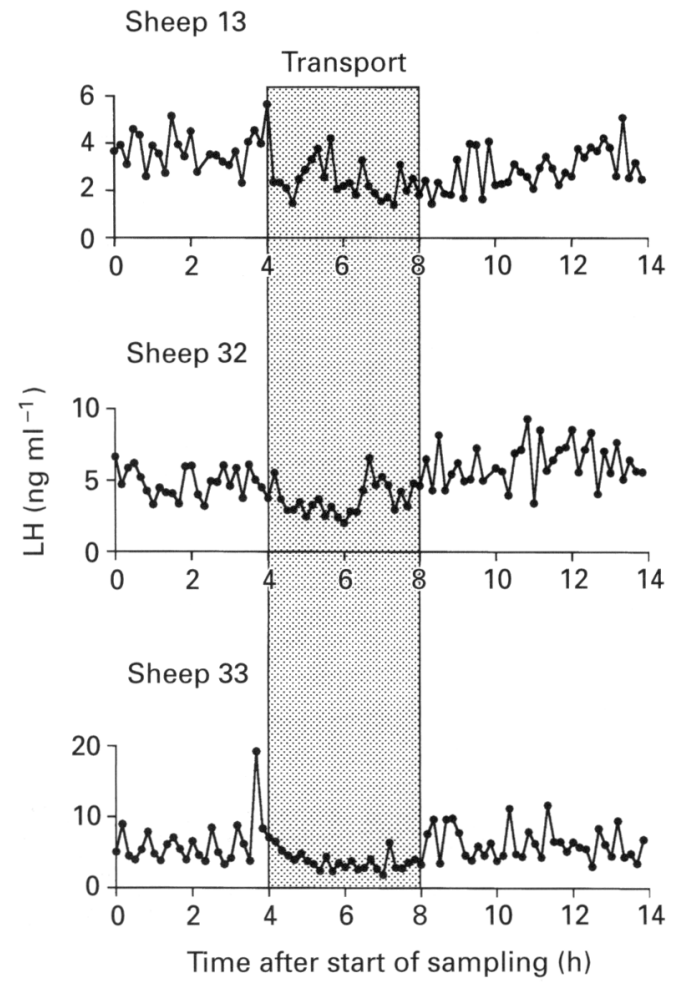

Fig. 3. Profiles of LH in the peripheral plasma of three representative ovariectomized ewes transported (․․) for $4 \mathrm{~h}$ in the midbreeding season without prior steroid treatment (Expt 1).

variable response, no statistical analysis was carried out on these data.

Experiment 1: mid-breeding season, no prior steroids. Transport of ovariectomized ewes in the absence of recent steroid pretreatment reduced LH pulsatility (for example, see Fig. 3). A detailed analysis of the LH pulse characteristics is given (Table 1). Transport reduced pulse frequency $(P<$ $0.05)$ and LH pulse amplitude $(P<0.001)$, with consequent marked effects on area, nadir and mean concentrations. These last three parameters were related directly to pulse frequency and amplitude within the present experimental design (Table 1), hence, in the interests of brevity, further LH analysis is restricted to pulse frequency and amplitude.

Experiment 2: mid-breeding season, with prior steroids. The LH pulsatility was depressed during transport (for example, see Fig. 4, which shows the same three ewes shown in Fig. 3). Mean data for all ewes revealed a suppressive effect of transport on pulse frequency, with only a tendency of effect $(P=0.07)$ on amplitude, possibly because of the large variance prior to transport (Fig. 5).

Comparison of data from the same eight ewes in Expts 1 and 2 showed that LH pulse frequency, but not amplitude, for the period before transport was significantly reduced by prior treatment with oestradiol and progesterone even $34 \mathrm{~h}$ after steroid removal (Fig. 5); again, note the large pretransport variability in pulse amplitude.

Experiment 3: transition into anoestrus, with prior steroids. When the pilot experiment was repeated in the next year in all 12 ewes, LH pulsatility was seasonally suppressed in only one ewe but LH pulsatility increased during transport. Six of the remaining 11 ewes initially displayed robust pulsatility, which was depressed during transport (Fig. 5). The pulsatile LH profile was not affected by transport in the remaining five ewes (data not shown). Comparison of pulse characteristics in the period before transport between Expts 2 and 3 (Fig. 5) revealed that pulse frequency, but not amplitude, in the transition period was lower than it was during the breeding season after steroid pretreatment.

Experiment 4: anoestrus, with or without prior steroids. Without steroid treatment in anoestrus (Expt 4a), an effect of transport on LH pulse frequency was not observed but there was a significant decrease in amplitude $(P<0.02$; Fig. 6). After steroid pretreatment in Expt $4 \mathrm{~b}$, initial pulse frequency and amplitude were lower than in ewes that had not been exposed to steroids for 4 months. However, these parameters were not further affected by transport. Those ewes retaining the oestradiol implant (Expt $4 \mathrm{c}$ ) had very low concentrations of $\mathrm{LH}$ but neither pulse amplitude nor frequency were significantly increased or decreased by transport (Fig. 6).

Experiment 5: anoestrus, recently ovariectomized ewes, with or without prior steroids. Ewes in Expt 5a ovariectomized 14-21 days previously had fewer LH pulses of lower amplitude than those ewes in Expt 4a that had not been exposed to steroids for 4 months (Fig. 6). Retention of the small oestradiol implant reduced pulse amplitude in Expt $5 b$ but again there was no significant effect of transport during anoestrus in recently ovariectomized ewes, with or without steroid treatment (Fig. 6). The reason for the low pulse frequency after transport in Expt $5 b$ is unknown.

Experiment 6: anoestrus, intact ewes without prior exogenous steroids. These intact ewes had lower LH pulse frequency and amplitude than those in Expt $4 \mathrm{a}$ but were unaffected by transport (Fig. 6).

\section{Progesterone and cortisol}

The peripheral plasma progesterone concentrations in six ovariectomized ewes pretreated with or without two CIDRGs (Expts 1 and 2) are shown (Fig. 7). At 0 and $12 \mathrm{~h}$, progesterone concentrations after removal of the CIDR-Gs $(P<0.05)$ were greater than they were in the controls. By 20 and $34 \mathrm{~h}$ after removal of the CIDR-Gs, there was no difference in the peripheral progesterone concentrations between the groups.

The mean profiles of cortisol and progesterone obtained from five ewes transported during the breeding season, anoestrus or the transition period are shown (Fig. 8) (these five ewes include the three for which data are represented in Figs 3 and 4). Basal concentrations of cortisol were greater in anoestrus than in the breeding season $\left(13.8 \pm 2.5 \mathrm{ng} \mathrm{ml}^{-1}\right.$ versus $\left.5.4 \pm 1.3 \mathrm{ng} \mathrm{ml}^{-1} ; P<0.05\right)$. In each season, concentrations increased immediately from the start of transport but then decreased so that the amount released during the fourth hour of transport was lower than that during the first hour 
Table 1. Characteristics of LH pulses (mean \pm SEM) before ( $0-4 \mathrm{~h}$ ), during ( $4-8 \mathrm{~h})$ and after (10-14 h) transport for $4 \mathrm{~h}$ in 12 ovariectomized ewes in the breeding season with no prior steroid treatment (Expt 1)

\begin{tabular}{|c|c|c|c|c|}
\hline & Before transport & During transport & After transport & $\begin{array}{l}\text { a versus b } P \text { value } \\
\text { (Student's } t \text { test) }\end{array}$ \\
\hline Mean number pulses (per $4 \mathrm{~h}$ ) & $7.25 \pm 0.28^{a}$ & $6.33 \pm 0.31^{b}$ & $6.83 \pm 0.24$ & $<0.04$ \\
\hline Mean pulse amplitude (ng ml-1) & $2.75 \pm 0.45^{\mathrm{a}}$ & $1.72 \pm 0.24^{\mathrm{b}}$ & $3.42 \pm 0.40$ & $<0.001$ \\
\hline Mean pulse area (arbitrary units) & $42.35 \pm 7.12^{\mathrm{a}}$ & $26.91 \pm 3.93^{b}$ & $51.48 \pm 6.05$ & $<0.05$ \\
\hline Mean nadir $\left(\mathrm{ng} \mathrm{ml}^{-1}\right)$ & $3.44 \pm 0.30^{3}$ & $2.87 \pm 0.34^{\mathrm{b}}$ & $4.09 \pm 0.33$ & $<0.001$ \\
\hline
\end{tabular}

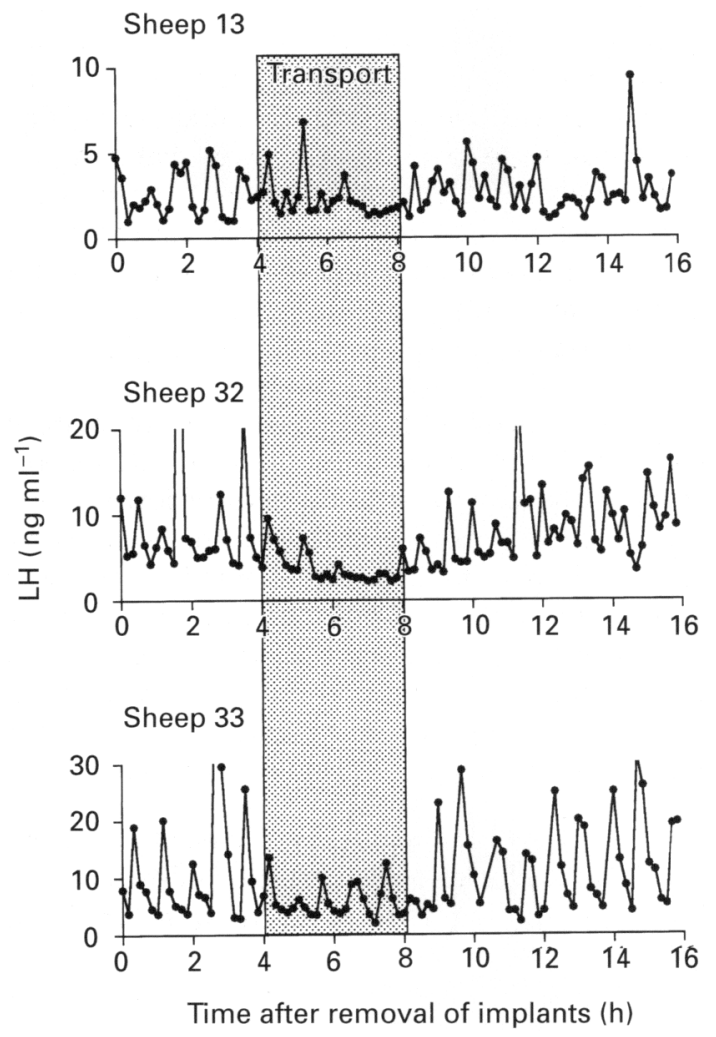

Fig. 4. Profile of LH in the peripheral plasma of three representative ovariectomized ewes transported ( 6 ) for $4 \mathrm{~h}$ in the mid-breeding season after removal of prior steroid treatment (Expt 2). Note the increased pre-transport variabilty in $\mathrm{LH}$ pulse amplitude as exemplified by the same three ewes in Fig. 3.

(compared in terms of area under curve for each hour; $P=$ $0.05)$. In many, but not all, ewes, there was a subsequent increase in cortisol during unloading. Comparison of cortisol values $30 \mathrm{~min}$ after the start of transport showed that the greatest cortisol concentration increments occurred during the transition period $\left(23.3 \pm 4.5 \mathrm{ng} \mathrm{ml}^{-1}\right.$ versus $17.4 \pm 3.5 \mathrm{ng}$ $\mathrm{ml}^{-1}$ in anoestrus, and $15.1 \pm 3.0 \mathrm{ng} \mathrm{ml}^{-1}$ in the breeding season; $P<0.05$, ANOVA; Fig. 8). However, the increment in cortisol values above baseline during transport was similar in anoestrus and the breeding season. There were no differences in cortisol or progesterone profiles between those animals with a concomitant increase in LH pulsatility and those with a decrease in LH pulsatility. Progesterone concentrations in peripheral plasma increased from $0.31 \pm$

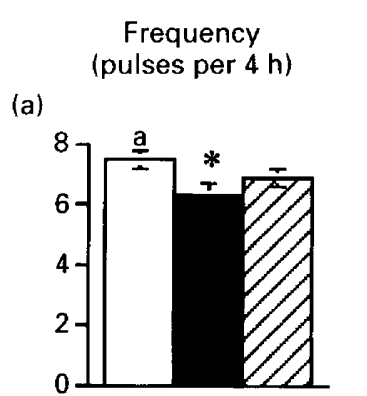

Amplitude (ng LH ml-1)

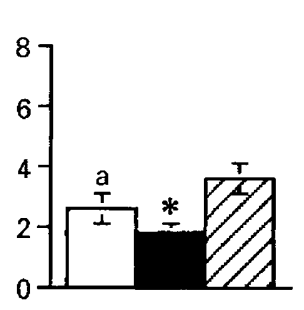

(b)
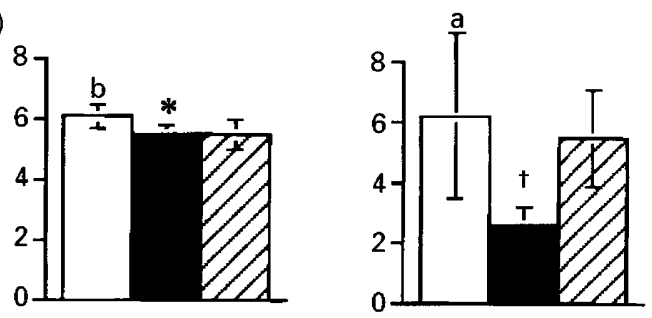

(c)
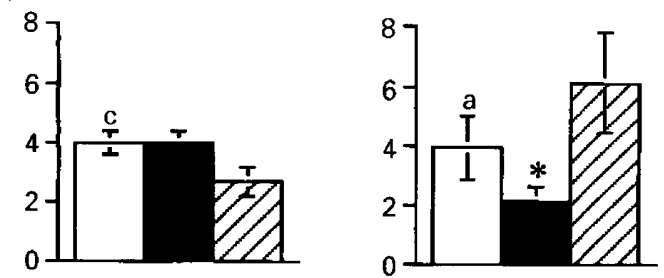

Fig. 5. Mean \pm SEM frequency (left panels) and amplitude (right panels) of LH pulses in 6-12 ovariectomized ewes before ( $0-4 \mathrm{~h}$; $\square$ ), during $(4-8 \mathrm{~h} ; \mathbf{\square})$ and after $(10-14 \mathrm{~h} ; \mathrm{Z})$ transport for $4 \mathrm{~h}$ in Expts $1-3$. (a) Expt 1: breeding season, no prior steroids; (b) Expt 2: breeding season, $34 \mathrm{~h}$ after steroid withdrawal; and (c) Expt 3: transition period, $34 \mathrm{~h}$ after steroid withdrawal. Expt 3 is represented by the six ewes in which LH pulsatility was reduced by transport. For comparisons within ewes before and during transport: $* P<0.05$; ${ }^{\dagger} P=0.07$. For comparisons between Expts in the period before transport, values with different superscripts are significantly different $(P<0.05)$.

$0.02 \mathrm{ng} \mathrm{ml}^{-1}$ before transport to $0.46 \pm 0.05$ and $0.48 \pm 0.05 \mathrm{ng}$ $\mathrm{ml}^{-1}$ during the first and second hours of transport $(P<0.05)$, respectively. There was no difference in increments between seasons. 
(a)

Frequency

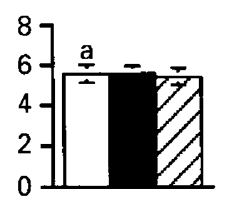

(b)

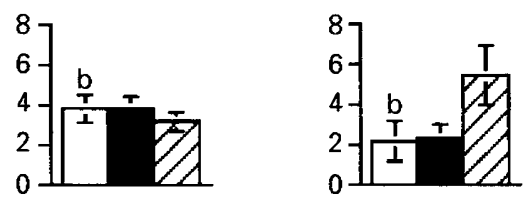

(c)

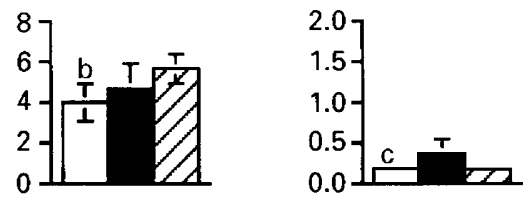

(d)

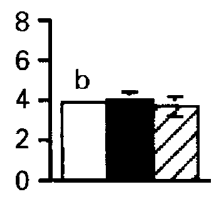

(e)

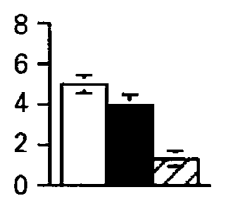

(f)
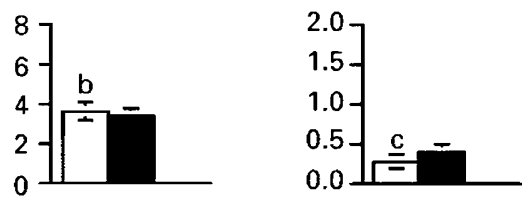

Fig. 6. Mean \pm SEM frequency (left panels) and amplitude (right panels) of LH pulses in 6-12 ovariectomized ewes before $(0-4 \mathrm{~h} ; \square)$, during (4-8 h; $\square$ ) and after $(10-14 \mathrm{~h} ; \circlearrowright)$ transport for $4 \mathrm{~h}$ in Expts 4-6. (a) Expt 4a: ewes ovariectomized $>1$ year previously, no prior steroids; (b) Expt 4b: ewes ovariectomized $>1$ year previously, $3 \mathrm{~h}$ after steroid withdrawal; (c) Expt 4c: ewes ovariectomized $>1$ year previously, oestradiol remaining; (d) Expt 5a: ewes ovariectomized within the previous 2 weeks, no prior steroids; (e) Expt 5b: ewes ovariectomized within the previous 2 weeks, oestradiol remaining; (f) Expt 6: intact ewes, no exogenous steroids. For comparisons within ewes before and during transport, ${ }^{*} P<0.05$. For comparisons between Expts in the period before transport, values with different superscripts are significantly different, $P<0.05$. Note the different scales for LH pulse amplitude.

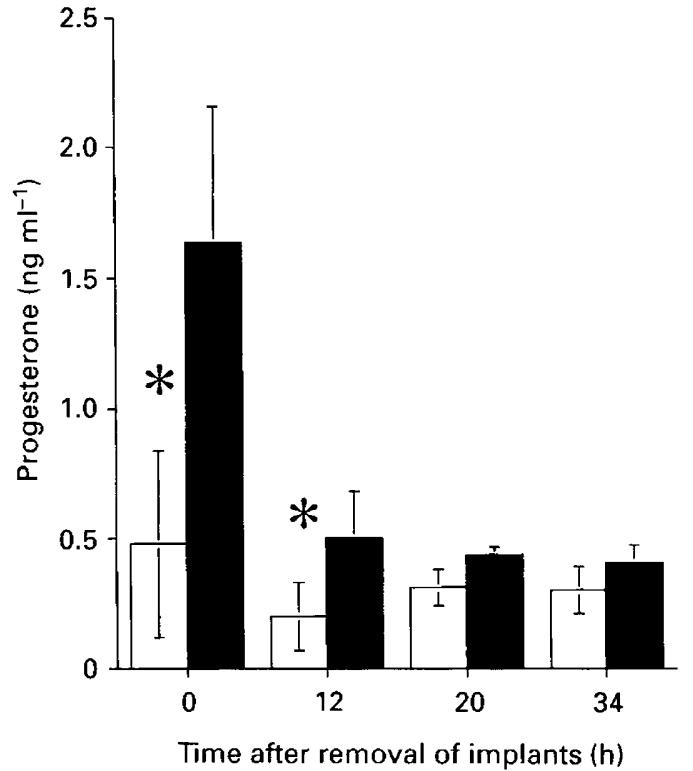

Fig. 7. Peripheral concentrations of progesterone (mean \pm SEM) in six ovariectomized ewes $0,12,20$ and $34 \mathrm{~h}$ after removal of none ( $\square$ ) or two $(\square)$ CIDR-Gs that had been inserted for 12 days in the breeding season. For comparisons within a time period, ${ }^{*} P<0.05$.
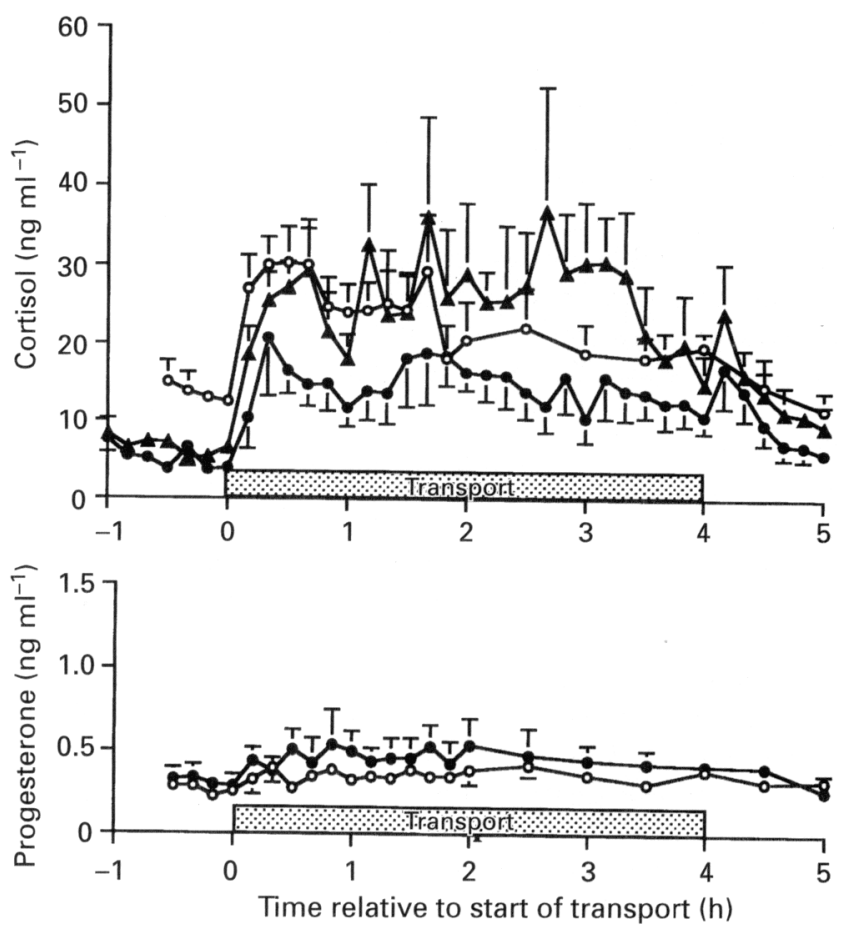

Fig. 8. Peripheral concentrations of cortisol and progesterone (mean \pm SEM) in five ovariectomized ewes around transport ( 0 ) during the breeding season (O), anoestrus $(0)$, and the transition period between the two $(\boldsymbol{A})$. Progesterone values in anoestrus were similar but have been omitted for clarity. 


\section{Discussion}

In the present study, a decrease in LH pulse amplitude during transport was revealed in ovariectomized ewes if prior steroids were absent for at least 4 months either in the breeding season or in anoestrus. Suppressive effects of transport on LH pulse frequency were also observed in the breeding season. Similar results during the breeding season were obtained after stress was induced by a challenge with endotoxin, and GnRH secretion was similarly disrupted, indicating effects within the hypothalamus (Battaglia et al., 1997). However, the presence of small amounts of oestradiol or progesterone did not reverse these effects in the breeding season or in anoestrus, as might have been expected from the CRH infusion studies of Caraty et al. (1997).

The lack of effect observed on LH pulse frequency in anoestrus may be explained by interaction with the feedback mechanisms that are involved in the seasonal control of $\mathrm{LH}$ pulsatile secretion. For example, if the effects of stressors to reduce LH pulsatility are mediated by the release of neurotransmitters (for example, catecholamines), such responses may be masked by the increased negative influence on similar neurotransmitter systems that are known to be effective during anoestrus in sheep (Goodman, 1994). Opioids and catecholamines have already been implicated in stress-reduced LH secretion in rats (Rivier and Rivest, 1991), and endogenous opioids and adrenergic neurones are known to control pulse amplitude in oestrous ewes (Goodman et al., 1995, 1996). However, direct effects on pulse amplitude at the pituitary must not be overlooked, as increased ACTH concentrations reduce GnRH-induced LH release by $50 \%$ in vitro (Phogat et al., 1997b).

It is not clear whether progesterone feedback mediates the suppressive effects of hypothalamus-pituitary-adrenal activation on LH pulsatility. The increment in peripheral progesterone concentrations during transport in the present experiment was very small $\left(0.16 \mathrm{ng} \mathrm{m}^{-1}\right)$ and, although Battaglia et al. (1997) suggested that an increment of $0.6 \mathrm{ng}$ $\mathrm{ml}^{-1}$ after endotoxin treatment was too little to have an effect, there are other situations in which similar small amounts have seriously compromised endocrine profiles. For example, progesterone concentrations of $0.66 \mathrm{ng} \mathrm{ml}^{-1}$ inhibited the appearance of an LH surge after oestradiol treatment in cyclic ewes (Pant, 1977), and an increment of $0.9 \mathrm{ng} \mathrm{ml}^{-1}$ caused an immediate decrease in LH-driven oestradiol production by dominant follicles in cows (Noble et al., 1996). All the above measurements were in peripheral plasma; assessment of concentrations on receptors in the hypothalamus would be more revealing. The seasonal effect of transport on pulse frequency could be explained by a progesterone-mediated event, as progesterone activates an increase in opioid tone but not in anoestrus, only during the breeding season (Yang et al., 1988). However, in general, progesterone negatively influences $\mathrm{LH}$ pulse frequency, with relatively little effect on amplitude (Goodman, 1994). Thus, if involved, progesterone may be only one of many factors influencing the effects of stressors on LH pulsatilty.

The basal concentrations of cortisol were greatest in anoestrus, confirming other observations in rams and ewes (Ssewannyana et al., 1990). The increment in response to a stressor was similar in anoestrus and the breeding season but, in keeping with observations after exogenous ACTH stimulation (Ssewannyanna et al., 1990), the cortisol response to transport appeared to be greatest during the transition period between the breeding season and anoestrus. At this time, the adrenal glands, being more sensitive to either endogenous or exogenous ACTH, may secrete greater quantities of compounds, which can cause increased LH release from the pituitary.

Most of the present results are difficult to reconcile with the previously reported stimulatory effects of intracerebrally administered corticotrophin releasing factor on LH pulsatility, along with the suggestion that such effects are only mediated during steroid negative feedback (Naylor et al., 1990, Caraty et al., 1997). However, in the present experiment, during the transition into anoestrus, an increase in LH pulsatility did occur during transport, but only in those animals in which oestradiol negative feedback was operative. At this time, the hypothalamus-pituitary axis would be increasingly suppressed by oestradiol via thyroidmediated negative feedback (Legan et al., 1977; Webster et al., 1991). This event involves action at the hypothalamic pulse generator resulting in a reduction of $\mathrm{GnRH}$ and $\mathrm{LH}$ pulsatility. Activation of the hypothalamus-pituitary-adrenal axis by a stressor reversed this negative effect probably by a hypothalamus-mediated mechanism. However, a similar reverse effect was not observed in oestradiol-treated ewes in mid-anoestrus. It is pertinent that the influence of the thyroid is mainly operative during the transition into anoestrus, whereas oestradiol is active throughout anoestrus (Webster et al., 1991). Changes in thyroid hormone secretion in response to stressors are unknown.

The use of animals that had not been exposed for at least 4 months to oestradiol and progesterone was vindicated by the observed changes in LH secretion. In both anoestrus and the breeding season, prior treatment with steroids decreased pulse frequency in the period before transport, reflecting the well-characterized effect of these hormones (Goodman, 1994). The effect before transport on both pulse frequency and amplitude was still pronounced 14-21 days after ovariectomy (Expt 4a versus 5a) and $34 \mathrm{~h}$ after the removal of the steroids, when peripheral progesterone had returned to baseline concentrations (Expt 4 a versus $4 b$ ). Thus, steroid negative feedback at the hypothalamus was still clearly operative. Indeed, the failure to observe a differential suppressive effect of transport on LH pulse amplitude between long-term or recently ovariectomized anoestrous ewes may have been because the effects of pretreatment with steroids were still effective for days after steroid withdrawal.

In conclusion, the stress of transport reduced LH pulsatility with greatest effect during the breeding season. This finding adds to observations that transport also delays the LH surge mechanism with greater effect during the breeding season than in anoestrus (Dobson and Smith, 1995), probably by interfering with LH-dependent oestradiol production in the preovulatory period (Dobson et al., 1999b). It was not possible to confirm that increases in endogenous CRH (caused by the moderate stress of transport) result in increased LH pulsatility in the presence or absence of oestradiol or progesterone in the breeding season or anoestrus, as inferred by Caraty et al., 
(1997). However, in a few ewes during the transition into anoestrus in the present study, there was a reverse effect, with an increase in LH pulsatility during transport. Further explanation of the mechanism behind the suppressive effects of transport must also be able to incorporate an explanation for this reversed phenomenon.

The authors are grateful to H. Purcell, T. Roscoe, J. Sullivan, R. Hollis, C. O'Loughlin and M. Fowler for their technical help; to AFC (Bonn) for a training scholarship to M. Ozturk; the Wellcome Trust for a Fellowship to R. F. Smith and a vacation scholarship to $R$. Hollis; to Journals of Reproduction and Fertility Ltd for a vacation scholarship to J. Sullivan; to Richard Bass, Nigel Jones and his staff for care of the sheep; and to NIAMDD, Bethesda, MD for gonadotrophin assay reagents.

\section{References}

Alam MGS, Dobson H and Fitzpatrick RJ (1986) Endocrine response to different doses of ACTH in cows British Veterinary fournal 142 239-245

Battaglia DF, Bowen JM, Krasa HB, Thrun LA, Viguie C and Karsch FJ (1997) Endotoxin inhibits the neuroendocrine axis while stimulating adrenal steroids: a simultaneous view from hypophyseal portal and peripheral blood Endocrinology 138 4273-4281

Campbell BK, Dobson H and Scaramuzzi RJ (1998) Ovarian function in ewes made hypogonadal with GnRH antagonist and stimulated with FSH in the presence or absence of low amplitude LH pulses Journal of Endocrinology 156 213-222

Caraty A, Miller DW, Delaleu B and Martin GB (1997) Stimulation of LH secretion in sheep by central administration of corticotrophin-releasing hormone Journal of Reproduction and Fertility 111 249-257

Dobson H and Smith RF (1995) Stress and reproduction in farm animals Journal of Reproduction and Fertility Supplement 49 451-461

Dobson H and Ward WR (1977) Alterations in plasma gonadotrophin patterns caused by sodium pentabarbitone in ewes at oestrus and in anoestrous ewes after infusion of oestradiol Fournal of Endocrinology 75 109-118

Dobson H, Campbell BK and Scaramuzzi RJ (1997) Endocrine activity of induced persistent follicles in sheep Biology of Reproduction 56 208-213

Dobson H, Tebble JE, Phogat JB and Smith RF (1999a) Effect of transport on pulsatile and surge secretion of LH in ewes in the breeding season Journal of Reproduction and Fertility 116 1-8

Dobson H, Campbell BK, Scaramuzzi RJ and Baird DT (1999b) Effect of reducing LH pulse frequency and amplitude on ovarian oestradiol production in the ewe Journal of Reproduction and Fertility Supplement $\mathbf{5 4} 510$ (Abstract)

Goodman RL (1994) Neuroendocrine control of the ovine estrous cycle. In The Physiology of Reproduction 2nd Edn pp 659-709 Eds E Knobil and JD Neill. Raven Press, New York

Goodman RL, Parfitt DB, Evans NP, Dahl GE and Karsch FJ (1995) Endogenous opioid-peptides control the amplitude and shape of gonadotropin-releasing hormone pulses in the ewe Endocrinology 136 2412-2420
Goodman RL, Havern RL and Whisnant CS (1996) Alpha-adrenergic neurons inhibit luteinizing-hormone pulse amplitude in breeding-season ewes Biology of Reproduction 54 380-386

Kanchev LN, Dobson H, Ward WR and Fitzpatrick RJ (1976) Concentration of steroids in bovine peripheral plasma during the oestrous cycle and the effect of betamethasone treatment Journal of Reproduction and Fertility $\mathbf{4 8}$ 341-345

Kelly VM, Phogat JB, Smith RF, Deacon SE and Dobson H (1996) Pretreatment progesterone dose on the timing of the LH surge in ewes Acta Neurobiologiae Experimentalis $\mathbf{5 6} 845$

Legan SJ, Karsch FJ and Foster DL (1977) The endocrine control of seasonal reproduction function in the ewe: a marked change in response to the negative feedback action of estradiol on luteinizing hormone secretion Endocrinology 101 818-824

Moenter SM, Caraty A and Karsch FJ (1990) The estradiol-induced surge of gonadotropin-releasing hormone in the ewe Endocrinology 127 1375-1384

Naylor AM, Porter DWF and Lincoln DW (1990) Central administration of corticotropin-releasing factor in the sheep - effects on secretion of gonadotropins, prolactin and cortisol Journal of Endocrinology 124 117-125

Noble KM, Harvey D, Tebble JE, Deacon S, Jones N and Dobson H (1996) Structure, endocrine function and progesterone treatment of persistent follicles in cattle 14th World Biuatrics Congress, Edinburgh Poster 99

Ozturk M, Smith RF and Dobson H (1998) Effect of prolonged exposure to oestradiol on subsequent LH secretion in ewes Journal of Reproduction and Fertility 114 1-9

Pant HC (1977) Effect of oestradiol infusion on plasma gonadotrophins and ovarian activity in progesterone-primed and unprimed anoestrous ewes Journal of Endocrinology 75 227-233

Phogat PB, Smith RF and Dobson H (1997a) The influence of stress on neuroendocrine control of the hypothalamic-pituitary-ovarian axis Veterinary Bulletin $67553-567$

Phogat JB, Smith RF and Dobson H (1997b) Effect of adrenocorticotrophic hormone on gonadotrophin releasing hormone-induced luteinizing hormone secretion in vitro. Animal Reproduction Science 48 53-65

Rivier C and Rivest S (1991) Effect of stress on the activity of the hypothalamic-pituitary-gonadal axis: peripheral and central mechanisms Biology of Reproduction 45 523-532

Smith RF, Gore SW, Phogat PB and Dobson H (1997) The psychological stress of transport stimulates both CRF and AVP secretion into hypophysial portal blood Journal of Endocrinology 152 Supplement P172

Ssewannyana E, Lincoln GA, Linton EA and Lowry PJ (1990) Regulation of the seasonal cycle of beta-endorphin and ACTH secretion into the peripheral blood of rams Journal of Endocrinology 124 443-454

Taylor PL (1987) Munro Hormone Pulse-Profile Analysis Elsevier, Amsterdam

Webster JR, Moenter SM, Woodfill CJI and Karsch FJ (1991) Role of the thyroid gland in seasonal reproduction 2. Thyroxine allows a seasonspecific suppression of gonadotropin secretion in sheep Endocrinology 129 176-183

Wheaton JE, Carlson KM, Windels HF and Johnston LJ (1993) CIDR - a new progesterone-releasing intravaginal device for induction of estrous and cycle control in sheep and goats Animal Reproduction Science 33 127-141

Yang K, Haynes NB, Lamming GE and Brooks AN (1988) Ovarian-steroid hormone involvement in endogenous opioid modulation of $\mathrm{LH}$ secretion in mature ewes during the breeding and non-breeding seasons Journal of Reproduction and Fertility 83 129-139 